Tersedia Secara Online di http://ojs.unik-kediri.ac.id/index.php/jurmateks/index

JURMATEKS

\title{
Pemanfaatan Limbah Galvalum Sebagai Substitusi Aggregat Kasar Pada
}

\section{Jobmix Beton}

\author{
M. Bahrudin ${ }^{1 *}$, A. I. Candra ${ }^{2}$, S. Winarto ${ }^{3}$ \\ ${ }^{1 * 2,3}$ Fakultas Teknik, Universitas Kadiri \\ E-mail :' ${ }^{\text {rudirudibae23@gmail.com }}$
}

\begin{tabular}{|c|c|}
\hline Article history: & \\
\hline Artikel masuk & : $15-10-2020$ \\
\hline Artikel revisi & : $19-10-2020$ \\
\hline Artikel diterima & : 20-10-2020 \\
\hline
\end{tabular}

Keywords :

Concrete, Compressive Strength, Waste, Rough Aggregate

Style IEEE dalam mensitasi artikel ini:

[2]

L. Bruno, "Kajian Kuat Tekan Beton Normal Menggunakan Standar SNI 7656-2012 Dan ASTM C 136-06," J. Chem. Inf. Model., vol. 53, no. 9, pp. 1689-1699, 2019, doi:

10.1017/CBO9781107415324.004.

\begin{abstract}
A B S T R A C T
Concrete is one of the construction materials that is widely used. Currently, variations in concrete are being studied. Galvalum waste has high tensile properties but is mild. Its lightweight properties are expected to reduce the weight of the concrete itself. The purpose of this study is to find out the value of strong press, absorption, weight type $(E)$, degree of saturation (Sr), moisture content (Wc), and porosity of the addition of galvalume waste. The method used is a experimental method. Variations in galvalum waste substitution used are $50 \%$ and $100 \%$ of the aggregate weight is rought the sample used in the form of a cylinder size of $15 \mathrm{~cm} \times 30 \mathrm{~cm}$ with the initial quality of $\mathrm{fc}^{\prime} 18.67$ Mpa. The results of the strong press test showed that the galvalum waste subtitution has not been able to exceed the initial quality of the plan. The highest test result was obtained at a percentage of $50 \%$ with a strong press score of $F C^{\prime} 17.94 \mathrm{Mpa}$. In the percentage, absorption test results are $0.010 \%$, the weight of the type is $2325 \mathrm{~kg} / \mathrm{m} 3$, the pore number is $0.00232 \%$, the water content is $0.108 \%$, and porosity is $0.00108 \%$.
\end{abstract}

\section{A B S T R A K}

Beton merupakan salah satu bahan konstruksi yang banyak dipergunakan. Saat ini, pengguanaan variasi pada beton sedang banyak diteliti. Limbah galvalum memiliki sifat tarik yang tinggi namun ringan. Sifatnya yang ringan diharapkan mampu mengurangi berat beton itu sendiri. Tujuan dari penelitian ini adalah untuk mengetahui nilai kuat tekan, absorpsi, berat jenis $(\mathrm{\gamma})$, angka pori (e),derajat kejenuhan ( $\mathrm{Sr}$ ), kadar air (Wc), dan porositas dari penambahan limbah galvalum. Metode yang digunakan merupakan metode eksperimen. Variasi pensubtitusi limbah galvalum yang digunakan yaitu $50 \%$ dan $100 \%$ dari berat agregat kasar. sampel yang digunakan berbentuk silinder ukuran $15 \mathrm{~cm}$ x $30 \mathrm{~cm}$ dengan mutu awal fc' $18.67 \mathrm{Mpa}$. Hasil uji kuat tekan menunjukkan bahwa subtitusi limbah galvalum belum mampu melebihi mutu awal rencana. Hasil uji tertinggi didapat pada prosentase 50\% dengan nilai kuat tekan fc' 17,94 Mpa. Pada prosentase tersebut, didapat hasil uji absropsi yaitu $0,010 \%$, berat 
jenis yaitu $2325 \mathrm{~kg} / \mathrm{m} 3$, angka pori yaitu $0,00232 \%$, kadar air yaitu $0,108 \%$ serta porositas yaitu $0,00108 \%$.

\section{Pendahuluan}

Beton merupakan batu buatan yang memiliki kuat tekan cukup tinggi, dibuat dari campuran semen, pasir, batu pecah dan air. Perbaikan kualitas dan sifat beton dapat dilakukan dengan berbagai cara mengganti serta menambah bahan semen dan agregat, sehingga menghasilkan sifat-sifat spesifik seperti beton ringan, beton berat, beton tahan bahan kimia tertentu [1][2] Kelebihan - kelebihan beton dibandingkan dengan bahan lainya, yaitu dengan harganya relatif murah, mempunyai kekuatan yang baik, bahan baku penyusun mudah di dapat, tahan lama.[3].

Inovasi teknologi beton selalu dituntut guna menjawab tantangan akan kebutuhan, beton yang dihasilkan mempunyai kualitas tinggi meliputi kekuatan dan daya tahan tanpa mengabaikan nilai ekonomis. Hal lain yang mendasari pemilihan dan penggunaan beton sebagai bahan konstruksi adalah factor efektifitas dan tingkat efisiensinya [4]. Secara umum bahan pengisi beton terbuat dari bahan bahan yang mudah diperoleh, mudah diolah (workability) dan mempunyai keawetan (durability) serta kekuatan (strength) yang baik [5]. Dari sifat yang dimiliki beton itulah menjadikan beton sebagai bahan alternatif untuk di kembangkan baik bentuk fisik maupun metode pelaksanaannya [6].

Pemakaian beton sudah populer, pada perkembangannya beton dicampuri dengan beberapa bahan tambahan baik bahan kimia maupun non kimia, Abu Ampas Tebu (AAT), abu sekam padi, styrofom dan polimer [7]. Peneleitian mengenai pengembangan beton sedang banyak dilakukan guna untuk mendapatkan beton dengan kualitas baik. Pemanfaatan limbah dalam campuran menjadi salah satu hal yang dapat dikembangkan. Salah satu limbah yang ada yaitu limbah galvalume [8]. Limbah galvalum merupakan sisa potongan galvalum yang sudah tidak terpakai, penulis ingin melakukan penelitian yang belum pernah di lakukan, perlu adanya pemanfaatan baru mengenai penambahan limbah galvalum sebagai substitusi agregat kasar yang berkaitan pada struktur beton. Tujuan dari penelitian ini adalah mengetahui prosentase optimum penambahan limbah galvalum sebagai substitusi agregat kasar yang menghasilkan kuat tekan yang paling maksimum.

\section{Tinjauan Pustaka}

Pengaruh penambahan serat galvalum az 150 pada beton ringan dengan teknologi foam terhadap modulus elastisitas, kuat tarik dan kuat tekan. Penelitian ini dilakukan 
bertujuan untuk mengetahui sejauh mana pengaruh penambahan serat galvalum dalam campuran beton terhadap kuat tarik dan kuat tekan.

\subsection{Pengertian Beton}

Beton terdiri atas agregat, semen dan air yang dicampur bersama-sama dalam keadaan plastis dan mudah untuk dikerjakan [9][10]. Karena sifat ini menyebabkan beton mudah untuk dibentuk sesuai dengan keinginan pengguna. Sesaat setelah pencampuran, pada adukan terjadi reaksi kimia yang pada umumnya bersifat hidrasi dan menghasilkan suatu pengerasan dan penambahan kekuatan.

\subsection{Mutu Beton}

Beton berdasarkan kelas dan mutu beton. Kelas dan mutu beton ini, dibedakan menjadi 3 kelas, yaitu:

1. Beton kelas I adalah beton untuk pekerjaan-pekerjaan non struktutral [11]. Untuk pelaksanaannya tidak diperlukan keahlian khusus.

2. Beton kelas II adalah beton untuk pekerjaan-pekerjaan struktural secara umum.. Beton kelas II dibagi dalam mutu-mutu standar B1, K 125, K 175, dan K 225.

3. Beton kelas III adalah beton untuk pekerjaan struktural yang lebih tinggi dari K 225 .

\subsection{Material Penyusun}

\subsubsection{Semen}

Semen merupakan campuran dari beberapa senyawa kimia yang bersifat hidrolis [12]. Hidrolis artinya apabila suatu bahan dicampur dengan air dalam jumlah tertentu akan mengikat bahan-bahan lain menjadi satu kesatuan massa yang dapat memadat dan mengeras serta tidak larut.

\subsubsection{Agregat}

Agregat adalah butiran mineral yang merupakan hasil disintegrasi alami batu-batuan atau juga berupa hasil mesin pemecah batu dengan memecah batu alami [13][14].

1. Agregat Halus (Pasir)

Pasir adalah salah satu jenis agragat yang dibutuhkan untuk bahan pembuatan beton yang berukuran mulai dari 0,0625 hingga $2 \mathrm{~mm}$. Pasir terbentuk karena adanya proses pelapukan fisik dan kimia pada batuan [15]. 
2. Agregat Kasar (Batu Pecah)

Agregat kasar dapat berupa kerikil, pecahan kerikil, batu pecah, terak tanur tiup atau beton semen hidrolis yang dipecah[16][17].

\subsubsection{Air}

Air merupakan bahan dasar pembuatan beton yang penting dan paling murah. Air berfungsi sebagai reaktor ( $\pm 25 \%$ berat semen) semen dan pelumas antar butir-butiran agregat. Selain itu, air juga diperlukan untuk perawatan beton [18]

\subsection{Material Pensubtitusi}

\subsubsection{Hollow Galvalum}

Hollow galvalum ini memiliki lapisan finishing yang mengandung unsur alumunium sebesar 55\%, unsur besi sebesar 43,5\% dan silicon sebesar 1,5\%. Kandungan unsur-unsur ini menambah daya tahan besi hollow galvalum dari karat [19].

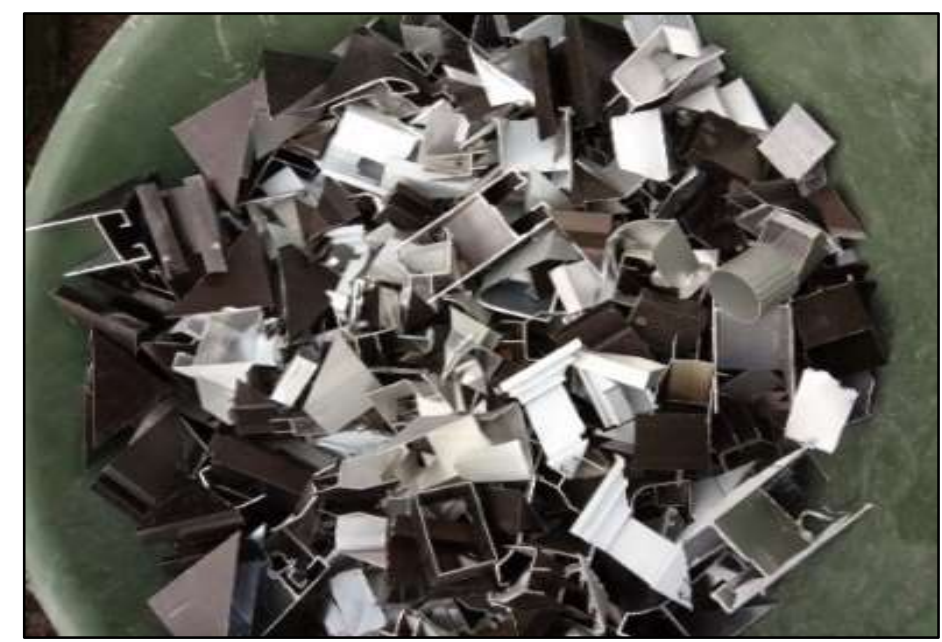

Sumber : Dokumentasi Pribadi.

Gambar 1. Limbah Galvalume.

\subsection{Pengujian Benda Uji}

Untuk mengetahui sifat-sifat dan kemampuan suatu material maka perlu dilakukan pengujian.Adapun karakteristik beton yang akan diuji antara lain [20]:

\subsubsection{Pengujian Kuat Tekan}

Kuat tekan beton adalah kemampuan suatu struktur beton menahan gaya tekan persatuan luas, dinyatakan dalam MPa atau $\mathrm{kg} / \mathrm{cm} 2$. Kekuatan tekan beton dihitung dengan rumus [13].

Pemanfaatan Limbah Galvalum Sebagai Substitusi Aggregat Kasar Pada Jobmix Beton 
$\mathrm{fc}^{\prime} \quad=\mathrm{P} / \mathrm{A}$

Dimana :

fc' = Kekuatan tekan $(\mathrm{MPa})$,

$\mathrm{P} \quad=$ beban tekan $(\mathrm{kN})$,

A $\quad=$ Luas permukaan benda uji $(\mathrm{cm} 2)$

Berdasarkan SNI 03 - 1974 - 1990 kuat tekan beton merupakan besarnya beban persatuan luas, yang menyebabkan benda uji beton hancur bila dibebani gaya tekan tertentu oleh mesin tekan [21].

\subsubsection{Absorpsi}

Absorpsi merupakan salah satu tolak ukur apakah beton nantinya dari segi keawetan dapat diandalkan atau tidak, setelah umur 28 hari. Besarnya absorpsi pada beton sesuai ASTM adalah:

At $=(\mathrm{Wt}-\mathrm{W} 0) \times 1000 / \mathrm{L} 1 \times \mathrm{L}$

Dimana :

$\mathrm{Wt}=$ Berat benda uji pada waktu $\mathrm{T}(\mathrm{gram})$,

W0 = Berat tetap awal benda uji (gram)

\subsubsection{Berat Jenis ( $\mathrm{\gamma})$}

Berat jenis adalah perbandingan relatif antara massa jenis sebuah zat dengan massa jenis air murni. Adapun rumus mencari berat jenis yaitu:

$\mathrm{y}=\mathrm{W} / \mathrm{V}$

Dimana :

$\mathrm{\gamma}=$ Berat jenis,

$\mathrm{W}=$ Berat Sampel,

$\mathrm{V}=$ Volume Sampel.

\subsubsection{Angka Pori (e)}

Angka pori didefinisikan sebagai perbandingan antara volume Void (Vv) dengan volume total (Vs). Adapun rumus mencari angka pori yaitu:

$\mathrm{e} \quad=V v / V s$

Dimana :

e $\quad=$ Angka Pori

Vv $=$ Volume Void

Vs $\quad=$ Volume Solid

Pemanfaatan Limbah Galvalum Sebagai Substitusi Aggregat Kasar Pada Jobmix Beton 


\subsubsection{Derajat Kejenuhan (Sr)}

Derajat kejenuhan didefinisikan sebagai perbandingan antara volume air dengan volume pori, yang dinyatakan dalam persen, Adapun rumus mencari derajat kejenuhan $(\mathrm{Sr})$ yaitu:

$\mathrm{Sr} \quad=(V w / V v)$

Dimana :

$\mathrm{Sr} \quad=$ Derajat Kejenuhan

Vw $\quad=$ Volume Air

$\mathrm{Vv} \quad=$ Volume Void.

\subsubsection{Kadar Air (Wc)}

Kadar air adalah sejumlah air yang terkandung didalam suatu benda seperti tanah, bebatuan, bahan pertanian, dan sebagainya. Kadar air di gunakan secara luas dalam bidang ilmiah, teknik, dan ditunjukkan dalam rasio, dari 0 (kering total) hingga nilai jenuh air dimana semua pori terisi air. Adapun rumus mencari kadar air yaitu:

$\mathrm{Wc}=(\mathrm{Ww} / \mathrm{Ws}) \times 100 \%$

Dimana :

Wc $=$ Kadar Air

$\mathrm{Ww}=$ Berat Air

Ws $\quad=$ Berat Sempel.

\subsubsection{Porositas}

Porositas merupakan persentase pori-pori atau ruang kosong dalam beton terhadap volume benda (volume total beton) Adapun rumus mencari porositas yaitu:

$\mathrm{n} \quad=\mathrm{e} /(1+\mathrm{e})$

Dimana :

$\mathrm{n} \quad=$ Porositas

$\mathrm{e} \quad=$ Angka Pori

\section{Metode Penelitian}

Metode dalam penelitian ini digunakan dengan metode eksperimen yang dilaksanakan di laboratorium kampus Univeritas Kadiri. Pengujian ini menggunakan benda uji silinder berukuran tinggi $30 \mathrm{~cm} \times$ diameter $15 \mathrm{~cm}$ dengan variasi prosentase $0 \%, 50 \%$, 
100\%. Benda uji yang akan digunakan berbentuk silinder. Benda akan diuji kuat tekan pada hari ke 28 hari [22].

\subsection{Alur Penelitian}

Secara garis besar, tahapan alur penelitian dapat dilihat seperti bagan di bawah ini :

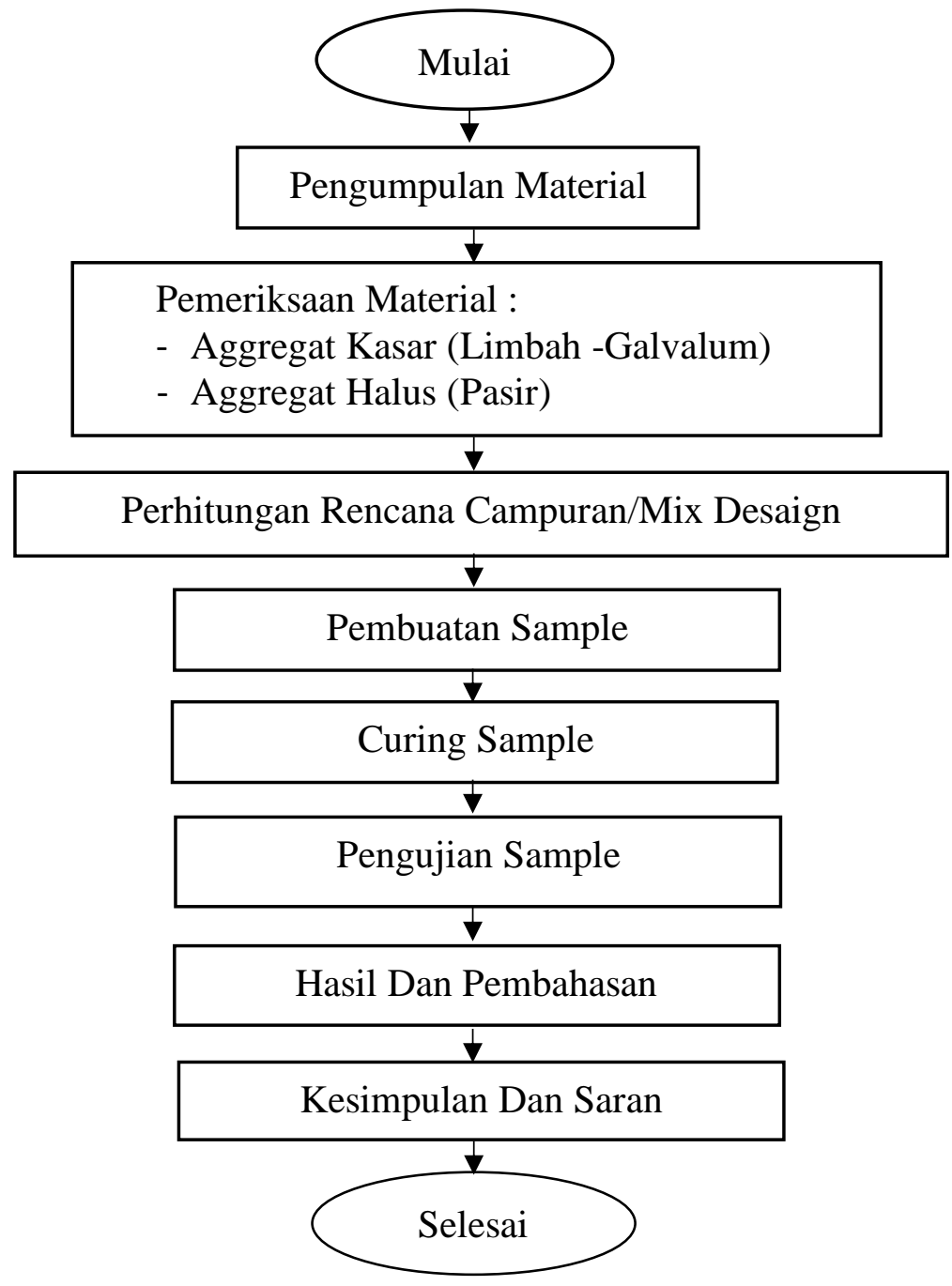

Sumber : Analisa Alur Penelitian.

Gambar 2. Bagan Alur Penelitian.

Pada tahapan ini seluruh bahan dan peralatan yang akan digunakan dalam penelitian dipersiapkan terlebih dahulu. Selanjutnya dilakukan pengujian material guna untuk menegtahui spesifikasi material yang digunakan, apakah material yang digunakan telah memenuhi persyartan atau belum . Apabila material telah memenuhi persyarata, dilakukan perhitungan rancangan campuran agar memperoleh komposisi campuran sesuai dengan target yang diharapkan. selanjutnya dilakukan pembuatan sampel dengan langkah-langkah sesuai SNI. Pada tahapan ini melakukan perawatan sampel/ curing pada benda uji. Perawatan beton dilakukan dengan cara merendam selama 28 hari. Terakhir dilakukan pengujian sampel. 


\section{Hasil dan Diskusi}

\subsection{Hasil Pengujian Kuat Tekan}

Dalam hal ini pengujian kuat tekan pada sempel adalah untuk mengetahui berapa kuat tekan optimum yang dihasilkan dari penambahan limbah galvalum sebagai substitusi agreat kasar pada jobmix beton. Adapun hasil pengujian kuat tekan pada sempel yang disajikan dalam bentuk grafik sebagai berikut :

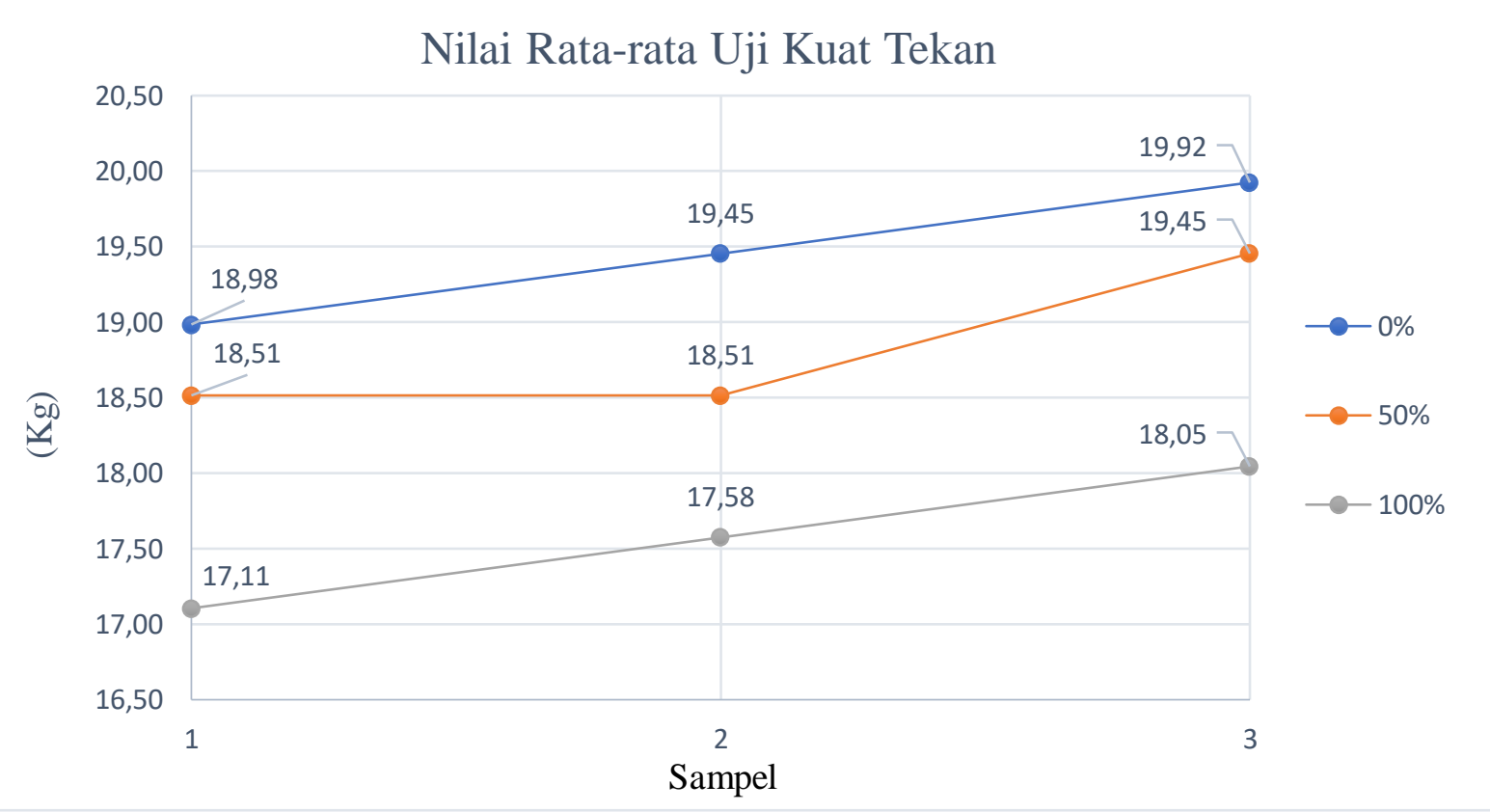

Sumber : Analisa Hasil Perhitungan Kuat Tekan.

Gambar 3. Grafik Nilai Rata-Rata Uji Kuat Tekan.

Dari Gambar 3. terlihat bahwa penggunaan limbah galvalum dengan prosentase $0 \%$ memiliki kuat tekan 18,98 Mpa, 19,45 Mpa, 19,92 Mpa. Prosentase 50\% didapat nilai kuat tekan 18,51 Mpa, 18,51 Mpa, 1945 Mpa. Prosentase 100\% didapat nilai kuat tekan 17,11 Мpa, 17,58 Мpa, 18,05 Mpa.

\subsection{Hasil Pengujian Absorpsi (At)}

Pengujian absorpsi atau penyerapan air oleh benda uji dimaksud untuk mengetahui berapa nilai dan pengaruh subtitusi agregat kasar pada jobmix beton terhadap daya serapnya pada air. Hal ini menggunakan penyerapan secara bertahap yaitu dalam waktu 1/4 jam, 1 jam, 4 jam dan 24 jam, berikut hasil rata-rata dalam bentuk grafik. 


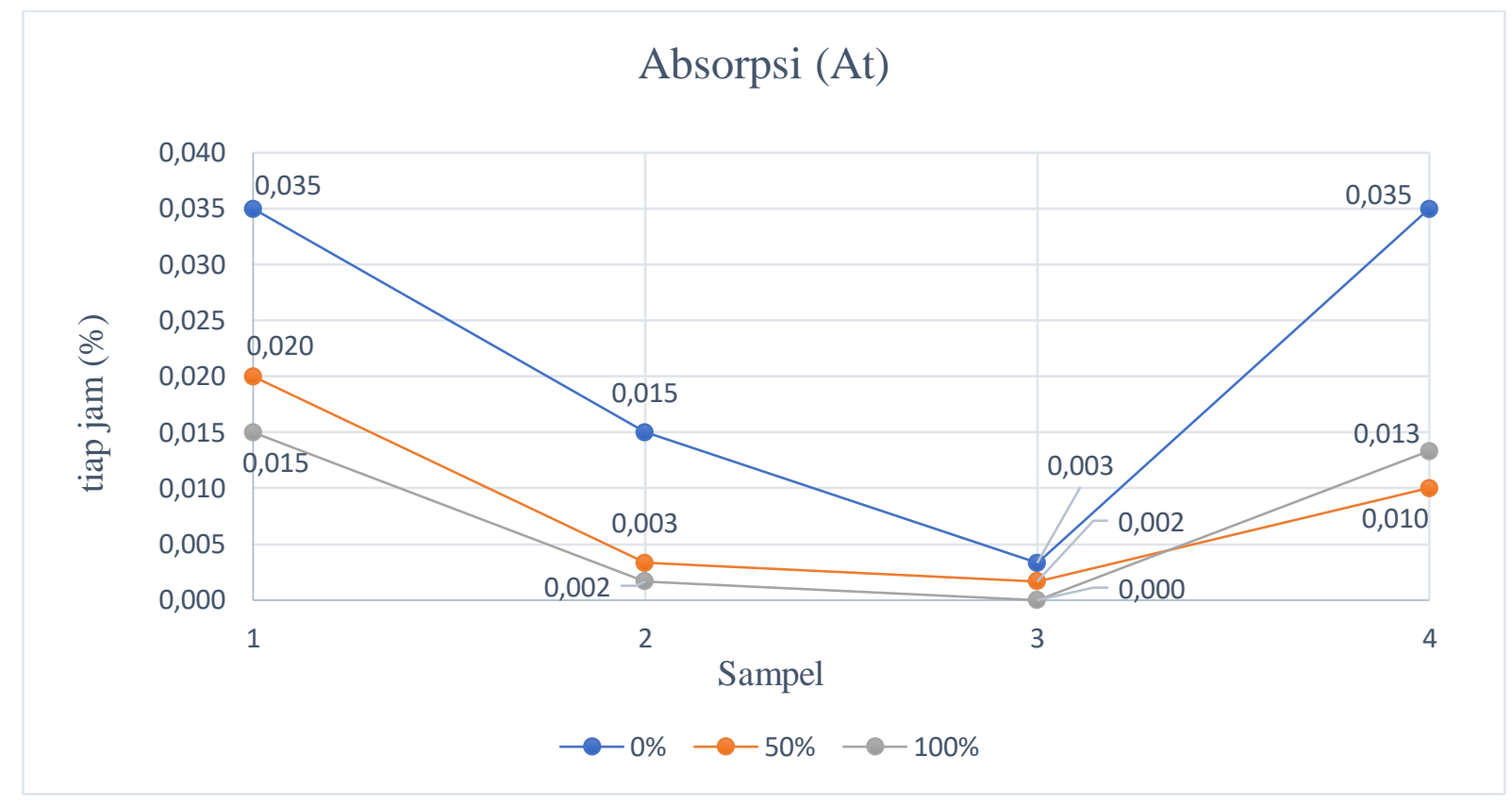

Sumber : Analisa Perhitungan Pengujian Absorpsi.

Gambar 4. Grafik Nilai Rata-rata Pengujian Absorpsi Tiap Jam.

Dari Gambar 4. didapat nilai absorpsi saat 1/4 jam, 1 jam, 4 jam, dan 24 jam, pada tiap variasi yaitu ; pada prosentase $0 \%$ memiliki nilai penyerapan $0,035 \%, 0,015 \%, 0,003 \%$, dan $0,035 \%$ pervariasi jam. Pada prosentasi $50 \%$ memiliki nilai penyerapan 0,020\%, 0,003\%, $0,002 \%$, dan $0,010 \%$ pervariasi jam. Pada prosentase $100 \%$ memiliki nilai penyerapan $0,015 \%, 0,002 \%, 0,000 \%$ dan $0,013 \%$.

\subsection{Hasil Pengujian Berat Jenis $(\gamma)$}

Hasil pengujian berat jenis diuraikan pada grafik berikut :

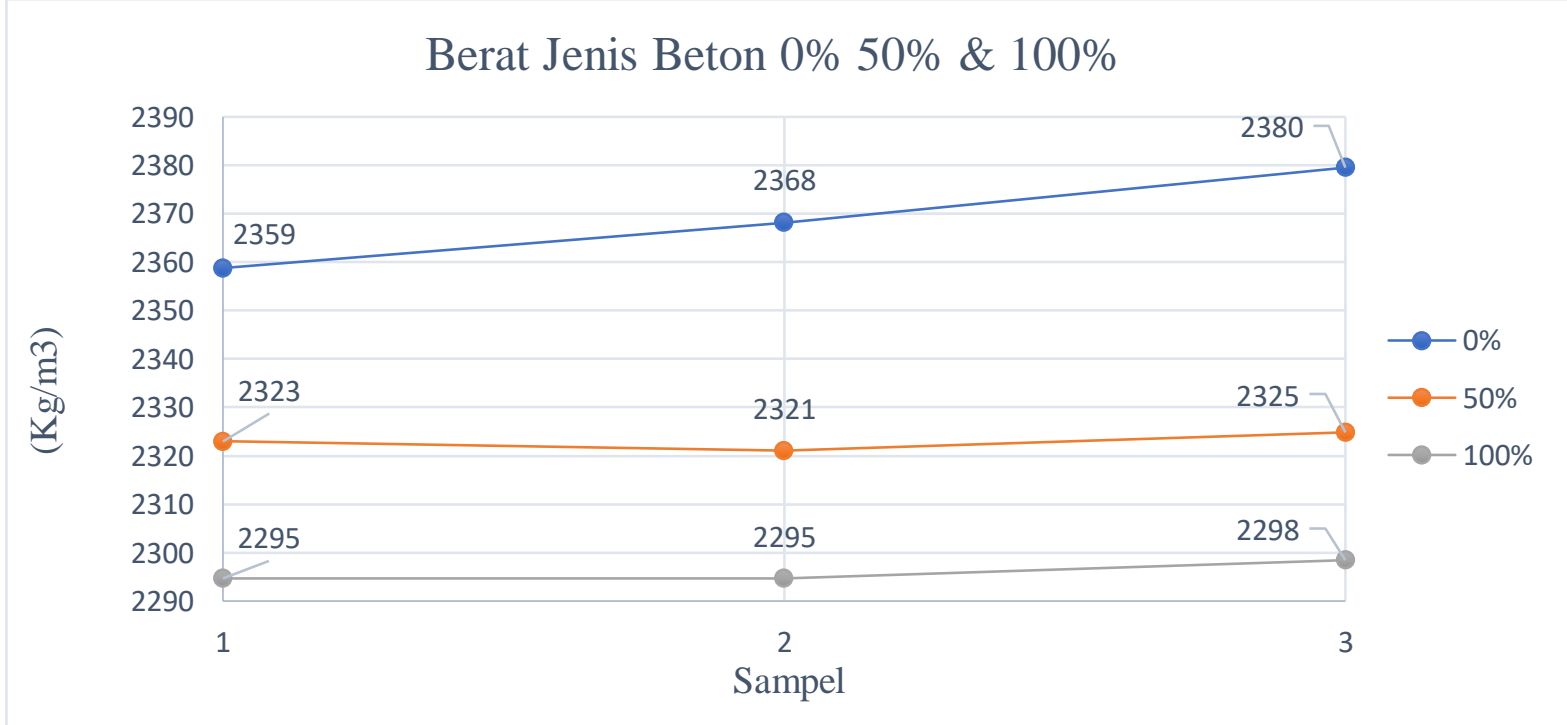

Sumber : Analisa Hasil Perhitungan Berat Jenis.

Gambar 5. Hasil Pengujian Berat Jenis. 
Berdasarkan grafik pada Gambar 5. berat jenis beton memiliki berat yang berbeda setiap prosentase, yaitu pada prosentase $0 \%$ memiliki berat jenis $2359 \mathrm{~kg} / \mathrm{m} 3,2368 \mathrm{~kg} / \mathrm{m} 3 \mathrm{dan}$ $2380 \mathrm{~kg} / \mathrm{m} 3$.Pada prosentase $50 \%$ memiliki berat jenis $2323 \mathrm{~kg} / \mathrm{m} 3,2321 \mathrm{~kg} / \mathrm{m} 3$ dan 2325 $\mathrm{kg} / \mathrm{m} 3$. Pada prosentase $100 \%$ memiliki berat jenis $2295 \mathrm{~kg} / \mathrm{m} 3,2295 \mathrm{~kg} / \mathrm{m} 3$ dan $2298 \mathrm{~kg} / \mathrm{m} 3$.

\subsection{Hasil Pengujian Angka Pori (e)}

Pengujian angka pori pada benda uji bertujuan untuk mengetahui berapa nilai angka pori pada sempel dari penambahan limbah galvalume sebagai substitusi agregat kasar pada jobmix beton. Untuk lebih jelasnya disajikan dalam bentuk grafik sebagai berikut :

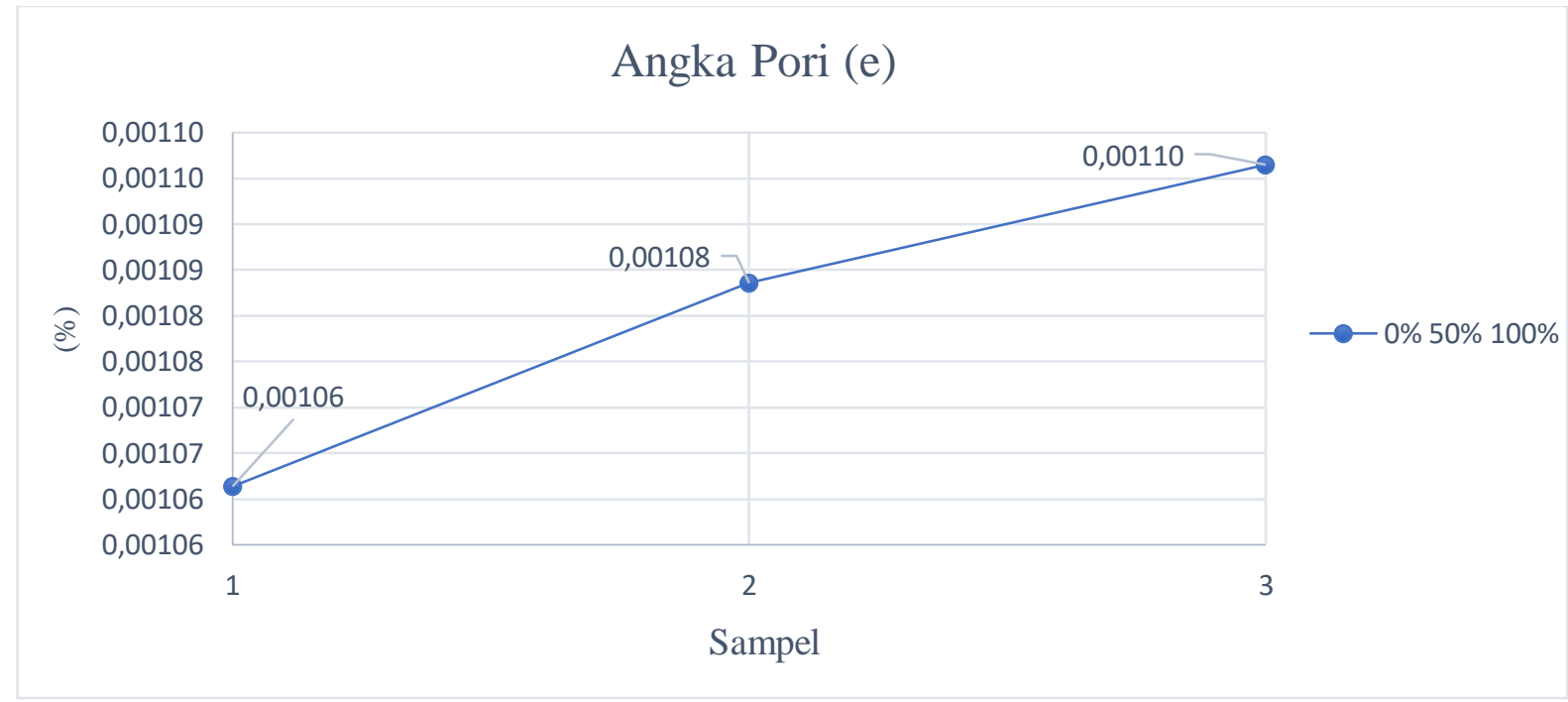

Sumber : Analisa Hasil Perhitungan Pengujian Angka Pori.

Gambar 6. Grafik Hasil Uji Angka Pori.

Berdasarkan grafik pada Gambar 6. jelas bahwa angka pori (e) pada prosentase 0\% memiliki nilai rata-rata 0,00106 , prosentase $50 \%$ memiliki nilai rata-rata 0,00108 , dan prosentase $100 \%$ memiliki nilai rata-rata 0,00110 . 


\subsection{Hasil Pengujian Derajat Kejenuhan (Sr)}

Hasil pengujian derajat kejenuhan dapat dilihat pada tabel berikut

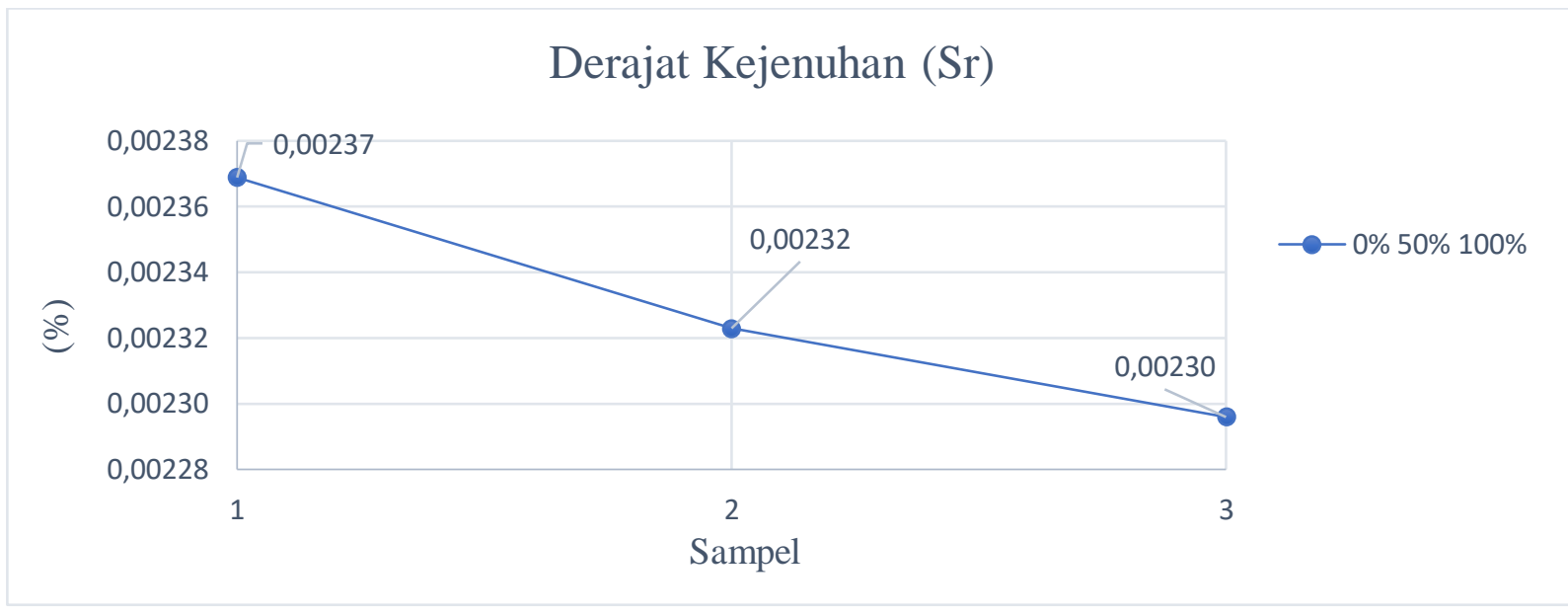

Sumber : Analisa Perhitungan Pengujian Derajat Kejenuhan.

Gambar 7. Hasil Uji Derajat Kejenuhan.

Dilihat dari grafik hasil uji derajat kejenuhan pada Gambar 7. prosentase $0 \%$ mendapatkan nilai rata-rata $0,00237 \%$ lebih tinggi dari prosentase $50 \%$ dengan nilai rata-rata $0,00232 \%$ dan prosentase $100 \%$ dengan nilai rata-rata $0,00230 \%$.

\subsection{Hasil Pengujian Kadar Air (Wc)}

Pengujian kadar air ditujukan untuk menentukan berat air yaitu berat basah dikurangi berat kering benda uji. Adapun hasil pengujiannya terlihat pada grafik berikut:

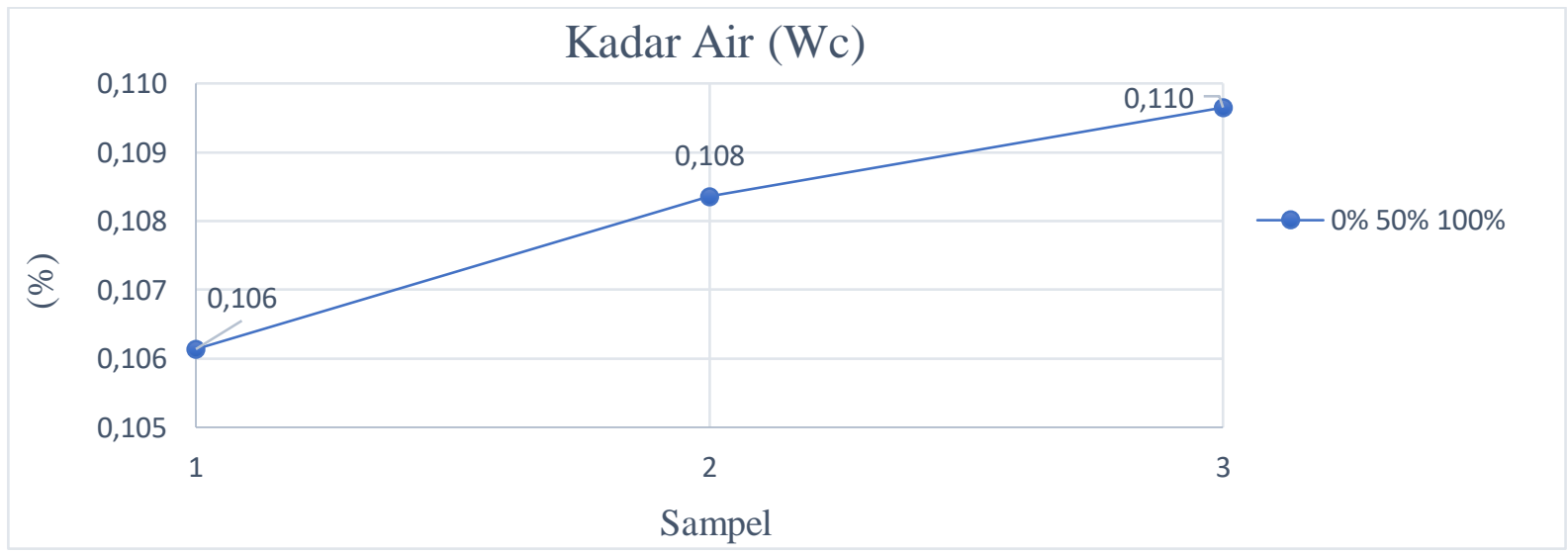

Sumber : Analisa Perhitungan Pengujian Kadar Air.

Gambar 8. Grafik Hasil Uji Kadar Air.

Berdasarkan grafik hasil uji kadar air pada Gambar 8. pada prosentase $0 \%$ memiliki nilai rata-rata $0,106 \%$, pada prosentase $50 \%$ memiliki nilai rata-rata $0,108 \%$, dan prosentase $100 \%$ memiliki nilai rata-rata $0,110 \%$. 


\subsection{Hasil Pengujian Porositas (n)}

Tujuan dari pengujian ini adalah untuk mengetahui nilai angka pori yang dihasilkan dari substitusi agregat kasar pada jobmix beton, untuk mengetahui porositas terlebih dahulu mengetahui nilai angka pori pada benda uji, adapun cara dan hasil dari pengujian di porositas yang sajikan dalam grafik pada Gambar 9.

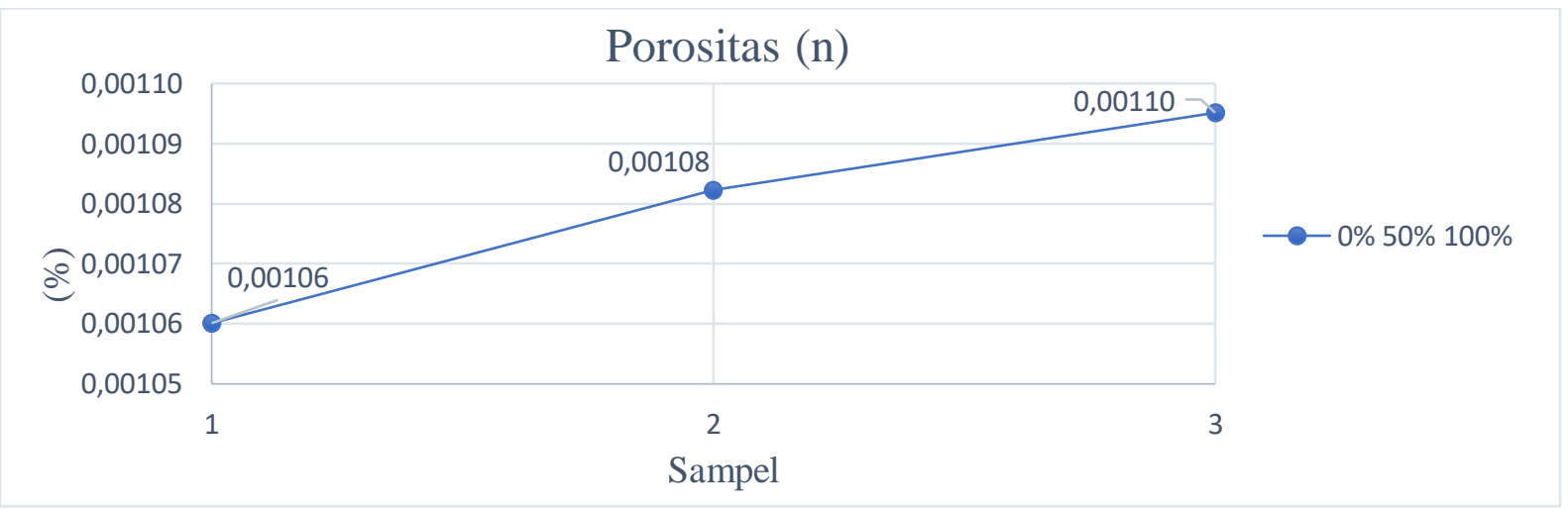

Sumber : Analisa Perhitungan Pengujian Porositas.

Gambar 9. Grafik Hasil Uji Porositas.

Dilihat dari grafik hasil uji porositas diatas, pada prosentase 0\% tanpa substitusi agregat kasar memiliki nilai rata-rata $0,00106 \%$. Pada prosentase pemanfaatan limbah galvalum sebagai substitusi agregat kasar pada job mix beton dengan prosentase $50 \%$ memiliki nilai rata-rata $0,00108 \%$ dan prosentase $100 \%$ memiliki nilai rata-rata $0,00110 \%$.

\section{Kesimpulan dan Saran}

\subsection{Kesimpulan}

Berdasarkan penelitian tentang pengaruh penambahan limbah galvalume sebagai substitusi agreagat kasar dalam pembuatan beton di Laboratorium Teknik Sipil Universitas Kadiri yang telah dilakukan dan hasil analisa data yang telah didapatkan dari pengamatan tersebut, maka dapat diambil kesimpulkan sebagai berikut.

1. Hasil pengujian kuat tekan beton dengan campuran normal dan dengan variasi penambahan limbah galvalume sebagai subtitusi agregat kasar pada umur 28 hari, memiliki rata-rata hasil kuat tekan yang berbeda. Nilai kuat tekan rata-rata beton tanpa adanya limbah galvalume sebagai substitusi agregat kasar yaitu 18,68 Mpa, sedangkan nilai kuat tekan rata-rata yang menggunakan variasi penambahan limbah galvalume sebagai substitusi agregat kasar 50\% sebesar 17,94 Mpa, dan variasi 100\% adalah sebesar 16,80 Mpa. 
2. Adapun hasil dari pengujian nilai berat jenis $(\gamma)$, angka pori (e), derajat kejenuhan (Sr), kadar air (Wc), Absorpsi (At) dan porositas (n) yang dihasilkan dari penambahan limbah galvalum .

a. Pengujian berat jenis mendapatkan rata-rata nilai sebesar $2369 \mathrm{~kg} / \mathrm{m} 3,2323 \mathrm{~kg} / \mathrm{m} 3$, dan $2296 \mathrm{~kg} / \mathrm{m} 3$, untuk variasi substitusi agregat kasar 0\%, 50\%, dan 100\%. Dengan demikian, substitusi agregat kasar memiliki berat jenis lebih rendah dibandingkan dengan benda uji tanpa substitusi agregat kasar.

b. Pengujian angka pori mendapatkan rata-rata nilai sebesar 0,00106, 0,00108, dan 0,00110. Untuk substitusi agregat kasar 0\%,50\% 100\%. Dengan demikian, substitusi agregat kasar memiliki angka pori lebih besar dari pada variasi beton tanpa substitusi agregat kasar.

c. Pada pengujian derajat kejenuhan mendapatkan rata-rata nilai derajat kejenuhan sebesar $0,00237 \%, 0,00232 \%, 0,00230 \%$, untuk variasi beton subtitusi agregat kasar 0\%, 50\%, dan 100\%. Dengan demikian, beton subtitusi agregat kasar lebih rendah dari pada variasi beton tanpa subtitusi.

d. Pengujian kadar air mendapatkan nilai rata-rata sebesar 0,106\%, 0,108\%, 0,110\%, Dengan demikian, subtitusi agregat kasar memiliki kadar air lebih tinggi dibandingkan dengan komposisi beton $0 \%$.

e. Dengan menggunakan penyerapan secara bertahap dalam waktu 1/4 jam, 1 jam, 4 jam dan 24 jam. Pada prosentase $0 \%$ memiliki nilai penyerapan 0,035\%, 0,015\%, 0,003\%, dan 0,035\% pervariasi jam. Pada prosentasi 50\% memiliki nilai penyerapan 0,020\%, $0,003 \%, 0,002 \%$, dan $0,010 \%$ pervariasi jam.Pada prosentase $100 \%$ memiliki nilai penyerapan $0,015 \%, 0,002 \%, 0,000 \%$ dan 0,013 pervariasi jam.

f. Pada pengujian porositas mendapatkan nilai rata-rata sebesar $0,00106 \%, 0,00108 \%$, dan 0,0084\%. Dengan demikian, subtitusi agregat kasar memiliki porositas lebih tinggi dari komposisi tanpa subtitusi agregat kasar.

\subsection{Saran}

Berdasarkan hasil kesimpulan diatas maka penulis dapat memberikan saran, yaitu untuk penelitian selanjutnya yang terkait dengan pemanfaatan limbah galvalum perlu dilakukanya perhitungan rencana anggaran biaya $(\mathrm{RAB})$, dan perlu dilakukannya penelitian lebih lanjut guna memproleh hasil yang lebih maksimal. 


\section{Daftar Pustaka}

[1] S. Needhidasan and P. Sai, "Demonstration on the limited substitution of coarse aggregate with the E-waste plastics in high strength concrete," Mater. Today Proc., vol. 22, pp. 1004-1009, 2020, doi: 10.1016/j.matpr.2019.11.255.

[2] L. Bruno, "Kajian Kuat Tekan Beton Normal Menggunakan Standar SNI 7656-2012 Dan ASTM C 136-06,” J. Chem. Inf. Model., vol. 53, no. 9, pp. 1689-1699, 2019, doi: 10.1017/CBO9781107415324.004.

[3] A. I. Candra and E. Siswanto, "Rekayasa Job Mix Beton Ringan Menggunakan Hydroton Dan Master Ease 5010,” J. CIVILA, vol. 3, no. 2, pp. 162-165, 2018.

[4] N. Suprihatin, “Tinjauan Kuat Tekan Dan Kuat Tarik Belah Beton Dengan Serat Kawat Bendrat Berbentuk 'W' Sebagai Bahan Tambah,' J. Teknol., vol. 1, no. 1, pp. 69-73, 2013, doi: 10.11113/jt.v56.60.

[5] E. J. Aprizal and P. Prapto, "Pengaruh Partial Replacement Semen Portland Dengan Bentonite Terhadap Kuat Tekan Beton Berdasarkan Variasi Umur," Inf. dan Ekspose Has. Ris. Tek. Sipil dan Arsit., vol. 11, no. 1, pp. 67-78, 2015.

[6] R. Irmawaty and A. A. Muhaimin, "Studi Perilaku Mekanik Beton Dengan Crumb Rubber," Univ. Hasanuddin. Gowa Makasar, 2015.

[7] Y. Rismayasari, U. U, and U. Santosa, "Pembuatan Beton dengan Campuran Limbah Plastik dan Karakterisasinya," Indones. J. Appl. Phys., vol. 2, no. 02, p. 24, 2016, doi: 10.13057/ijap.v2i02.1284.

[8] P. Gunawan and Setiono, "Foamed lightweight concrete tech using galvalum Az 150 fiber," Procedia Eng., vol. 95, no. Scescm, pp. 433-441, 2014, doi: 10.1016/j.proeng.2014.12.203.

[9] G. O. Bamigboye, O. Okara, D. E. Bassey, K. J. Jolayemi, and D. Ajimalofin, “The use of Senilia senilis seashells as a substitute for coarse aggregate in eco-friendly concrete," J. Build. Eng., vol. 32, no. September, p. 101811, 2020, doi: 10.1016/j.jobe.2020.101811.

[10] W. I. Dharmawan, D. Oktarina, and M. Safitri, "Perbandingan Nilai Kuat Tekan Beton Menggunakan Hammer Test dan Compression Testing Machine terhadap Beton Pasca Bakar," Media Komun. Tek. Sipil, vol. 22, no. 1, p. 35, 2016, doi: 10.14710/mkts.v22i1.12404.

[11] S. Zuraidah, "PENGARUH PENGGUNAN LIMBAH PAVING SEBAGAI ALTERNATIF AGREGAT KASAR UNTUK BETON,” J. Ilm. Kern, vol. 2, no. 2, pp. 
69-72, 2012, doi: 10.1080/15226510701603858.

[12] M. Farhan, "Penambahan Abu Batubara sebagai Bahan Campuran untuk Proses Pembuatan Semen,” Diss Politek. Negeri Sriwij., 2016.

[13] D. Haryanto, "Pemanfaatan Limbah Senyawa Lateks Karet Alam pada Beton Polimer dengan Pengisi Serbuk Cangkang Telur Ayam dan Pengeras Poliester," Repos. USU, 2018.

[14] K. Srinivas, S. Kranthi Vijaya, and K. Jagadeeswari, "Concrete with ceramic and granite waste as coarse aggregate," Mater. Today Proc., pp. 7-10, 2020, doi: 10.1016/j.matpr.2020.07.521.

[15] E. Gardjito, A. I. Candra, and Y. Cahyo, "Pengaruh Penambahan Batu Karang Sebagai Substitusi Agregat Halus Dalampembuatan Paving Block," UKaRsT, vol. 2, no. 1, pp. 36-42, 2018.

[16] A. I. Candra, H. Wahyudiono, S. Anam, and D. Aprillia, "KUAT TEKAN BETON Fc' $21,7 \mathrm{MPa}$ MENGGUNAKAN WATER REDUCING AND HIGH RANGE ADMIXTURES,” J. CIVILA, vol. 5, no. 1, pp. 330-339, 2020.

[17] A. V. Rahul and M. Santhanam, "Evaluating the printability of concretes containing lightweight coarse aggregates," Cem. Concr. Compos., vol. 109, no. February, p. 103570, 2020, doi: 10.1016/j.cemconcomp.2020.103570.

[18] A. I. Candra, E. Gardjito, Y. Cahyo, and G. A. Prasetyo, "Pemanfaatan Limbah Puntung Rokok Filter Sebagai Bahan Campuran Beton Ringan Berpori," UKaRsT, vol. 3, no. 1, p. 82, 2019, doi: 10.30737/ukarst.v3i1.365.

[19] R. C. Ardhisa, R. M. Maladzi, P. Sabdono, D. T. Sipil, F. Teknik, and U. Diponegoro, "Penggunaan bekisting galvalum bergelombang sebagai tulangan eksternal pada balok beton bertulang," J. karya Tek. sipil, vol. 6, 2017.

[20] Badan Standardisasi Nasional, "SNI 031973-2016 Metode uji Densitas, Volume Produksi Campuran Dan Kadar Udara (Gravimetrik) Beton,” 2016.

[21] S. Hidayat, "Tinjauan Kuat Tekan dan Kuat Tarik Belah Beton dengan Sebagian Semen Diganti Tanah Pozolan dari Kecamatan Tulakan,” Diss Univ. Muhamadiyah Surakarta, 2014.

[22] Badan Standardisasi Nasional, "SNI 03-1974-1990 Metode Pengujian Kuat Tekan Beton," 1990. 